\title{
Bigger stipends attract more UK postgrads into physics
}

London

The number of British graduates signing up for doctorates in physics and engineering has increased for the first time in three years. The rise could be in response to last year's $\mathfrak{E} 1,000$ (US $\$ 1,600$ ) increase in the value of the $\mathrm{PhD}$ stipend, bringing the minimum annual pay to $\mathfrak{E} 6,500$.

The increase will be especially welcomed by the Engineering and Physical Sciences Research Council (EPSRC), which has made offers on 92 per cent of its research studentships. Last year it filled only 85 per cent, and 560 studentship (including masters) places went unfilled - more than some councils actually offer (see Nature 397, 635; 1999).

The figures suggest that financial considerations have been responsible for the decline in interest in postgraduate research. Provisional figures on degree grades also indicate an increase in the qualifications of graduates taking on studentships in particle physics and astronomy (see table).

Providing staff to industry and academia is increasingly seen as a core function of the research councils. If confirmed across all

\begin{tabular}{|c|c|c|c|c|}
\hline \multicolumn{5}{|c|}{$\begin{array}{l}\text { Increase in take-up of UK research } \\
\text { studentships } 1998 \text { to } 1999\end{array}$} \\
\hline \multirow[b]{2}{*}{$\begin{array}{l}\text { Research } \\
\text { council }\end{array}$} & \multicolumn{2}{|c|}{1998} & \multicolumn{2}{|c|}{1999} \\
\hline & Take-up & Firsts & Take-up & Firsts \\
\hline EPSRC & $85 \%$ & $41 \%$ & $92.3 \%$ & $40.1 \%$ \\
\hline PPARC & $91.1 \%$ & $48 \%$ & $97.6 \%$ & $57 \%$ \\
\hline
\end{tabular}

1998 figures are final; 1999 figures are provisional.

councils, the increase will be welcome news, as the councils are currently preparing to report to the government on how well they are managing their budget, to help determine the next round of funding.

John Taylor, director-general of the research councils, has already told the councils that his Office of Science and Technology's funding proposals will focus on 'world class science,' 'people related' output, infrastructure, exploitation, and emerging priorities such as genomics and information technology.

The EPSRC figures remain equivocal. But take-up at the Particle Physics and Astronomy Research Council (PPARC) is now at 98 per cent, with nearly 60 per cent of students holding first-class degrees.
Natasha Loder

\section{Test ban treaty faces a rough ride from Senate Republicans}

Washington

US arms control advocates are concerned about whether they can secure anything close to the necessary two-thirds majority in next Tuesday's Senate vote on ratifying the Comprehensive Test Ban Treaty (CTBT).

Supporters of the treaty, including the American Physical Society, the Union of Concerned Scientists and several other scientific organizations, say that the hurried vote, only announced by the Senate leadership last week, makes it unlikely that many more Republican senators will join the two - Arlen Specter (Pennsylvania) and James Jeffords (Vermont) — who are supporting the treaty.

Thirty-two Nobel laureates in physics are expected to release a letter supporting the CTBT today (7 October). A defeat could set the treaty back several years, but some Democrat senators are keen for a vote, so they can attack Republicans who oppose a treaty supported by more than 80 per cent of voters. 